\title{
National culture as a driver of pro-environmental attitudes and behavioural intentions in tourism
}

\begin{abstract}
Voluntary changes in consumer behaviour hold significant potential to mitigate the growing environmental repercussions of tourism. Such behavioural changes can occur due to positive behavioural intentions that are in turn underpinned by pro-environmental consumer attitudes. To reinforce voluntary behavioural changes in tourism, it is paramount to understand the major drivers of pro-environmental consumer attitudes. Although national culture can influence pro-environmental attitudes of tourists, its role has been under-researched, especially in the context of emerging tourist markets. This study utilised the environmentorientated dimensions or value orientations of major cultural frameworks (Hofstede; Schwartz; Trompenaars and Hampden-Turner) to explore the effect of national culture on pro-environmental attitudes and behavioural intentions in a large-scale quantitative survey of Polish tourists. Correlation between the cultural background of tourists and their proenvironmental attitudes was established, thus highlighting the need for national culture to become an integral element of future scientific, policy-making and managerial discourse on the key drivers of more sustainable consumer behaviour in tourism.
\end{abstract}

\section{Keywords}

National culture; consumer attitudes; pro-environmental behaviour; sustainable tourism; Poland 


\section{Highlights}

- Explores how national culture influences pro-environmental attitudes of tourists

- Focuses on an emerging tourist market in East-Central Europe, Poland

- Finds correlation between national culture and pro-environmental attitudes

- Shows the validity of major cultural frameworks for the sustainable tourism context 


\section{Introduction}

Tourism imposes substantial environmental impacts (Gössling 2002) that have become particularly pronounced in terms of carbon footprint build-up (Peeters and Dubois 2010), water consumption (Gössling 2015) and waste generation (Trung and Kumar 2005). International tourist arrivals are expected to grow at an annual rate of 4-5\% (UNWTO 2018) emphasising the need to mitigate the increasing environmental repercussions of tourism (Gössling and Peeters 2015). Mitigation can be underpinned by technological innovations, regulatory interventions, and economic (dis)incentives (Filimonau and Högström 2017). It can further be achieved by facilitating voluntary, pro-environmental changes in consumer behaviour (McKercher et al. 2010). For most effective mitigation, a balanced mix of the above measures should be developed and applied (Gössling et al. 2012).

While voluntary behavioural changes can minimise the environmental impacts of tourism, they have been proven difficult to achieve (Budeanu 2007). Tourists have been found reluctant to change behaviour (Becken 2007), which is often determined by poor public understanding of the environmental implications of individual travel decisions (Becken 2004). Poor public understanding leads to indifferent consumer attitudes that, in turn, translate into irresponsible (or less responsible) behavioural practices among tourists (Gössling et al. 2012). It is therefore critical to enhance pro-environmental consumer attitudes in tourism, thus enabling more responsible patterns of tourist behaviour (Hall 2013). To this end, it is important to comprehend what drives pro-environmental attitudes of tourists and design accordingly the intervention measures for their reinforcement (Dolnicar et al. 2008).

National culture has for long been considered a potential driver of consumer attitudes and subsequent behaviour in various consumption contexts (Craig and Douglas 2006), including tourism (Moscardo 2004). This notwithstanding, the number of studies aiming to 
better understand the effect of national culture on tourist decision-making is limited ( $\mathrm{Li}$ 2014), especially when examining the role of cultural background in shaping proenvironmental attitudes in tourism (Nejati et al. 2015). This hampers the development of effective environmental mitigation measures in tourism as there is insufficient empirical evidence of the determinants of (more) responsible consumer choice (Chiu et al. 2014).

This study contributes to knowledge by exploring the role of national culture in shaping pro-environmental consumer attitudes in tourism that can subsequently facilitate changes towards more responsible, environment-benign tourist behaviour. To this end, via a largescale, quantitative consumer survey, it examines how specific, environment-related dimensions or value orientations of major cultural theories can drive pro-environmental attitudes of Polish tourists and how these attitudes can enable more responsible behavioural intentions. The focus on Poland is deliberate given a steady growth in its outbound tourism market (Central Statistical Office 2017a) and its relative cultural homogeneity (circa 97\% of residents are Poles) (Gonda 2006). It is further justified by the limited geographical scope of existing research on the role of national culture in pro-environmental consumer decisionmaking. Analysis has largely been restricted to the developed countries in the 'west' that represent the mainstay of tourist demand. The rapid growth of tourism in transitional economies of East-Central Europe as predicted by UNWTO (2018) suggests that these countries should now become integral elements of analysis.

\section{Literature review}

Tourist attitudes, behavioural intentions and behaviour

Tourist behaviour is difficult to predict as it is underpinned by the complexity of psychological (internal) and environmental (external) variables (Ajzen and Driver 1991). Van Vuuren and Slabbert (2011) posit that tourist behaviour is more complicated than generic 
consumer behaviour as it represents a multi-layered construct which should be analysed through a multidimensional and hierarchical lens (Stern 2000). Tourist behaviour is driven by a complex decision-making process, which can be pictured as a funnel with a broad base hosting the multiple decision-making variables (Yoo and Chon 2008). To aid in comprehending tourist behaviour, a number of specialised models have been developed (Mayo and Jarvis 1981; Moutinho 1987; also see Sirakaya and Woodside (2005) for a detailed overview). These models should however be taken with caution as they lack evidence of their empirical applicability to specific tourism contexts and further work is necessary to demonstrate their practical merit as implemented in real-life tourism settings (Bowen and Clarke 2009).

Among the internal drivers of tourist behaviour, tourist attitudes represent an important research object (Leonidou et al. 2015). While attitudes do not directly determine behaviour, they can influence behavioural intentions that, in turn, affect individual actions (Ajzen and Fishbein 1980). Indeed, negative consumer attitudes may lead to negative purchasing intentions and bring about negative behavioural patterns, such as boycotting specific products and/or their providers (Cohen et al. 2014). Better understanding of consumer attitudes is of particular relevance to the tourism context where negative consumer perceptions may impose a long-lasting, detrimental effect on business success (Gössling and Hall 2006). This can, for example, partially explain the reluctance of tourism and hospitality (especially small and medium-sized) enterprises to engage in environmental management initiatives in fear of causing negative perceptions among consumers, thus leading to reduced sales (Chan 2008). Therefore it becomes paramount to investigate consumer attitudes as a driver of tourist behaviour, especially in response to the potential pro-environmental operational changes envisaged by tourism enterprises, and demonstrate how this driver aligns with the future environmental commitments of tourism businesses (Jeong et al. 2014). 
Given the essential role played by voluntary behavioural changes in minimising the environmental impacts of tourism (Kim 2012), the research agenda on the drivers of proenvironmental tourist behaviour is evolving. It has mainly been concerned with drawing associations between public attitudes and pro-environmental behavioural intentions of tourists (Leonidou et al. 2015), with a primary focus on developed countries' populations (Dillimono and Dickinson 2015). Prime attention has been given to tourist transportation, with aviation representing the main study domain (Chapman 2007). This is because air travel makes a disproportionally high contribution to the environmental footprint of tourism due to the significant carbon intensity of its operations (Weaver 2011). Modal shift as facilitated by voluntary behavioural changes holds large potential to mitigate the environmental footprint of aviation (Scott et al. 2010). This has rationalised an expanding body of academic literature which has set to understand the relationship between public attitudes, behavioural intentions and tourist flying behaviour (Higham and Cohen 2011). Research has concluded that tourists often fail to establish links between their travel patterns and environmental impacts (Kroesen 2013). Studies have further shown that positive public attitudes do not always translate into pro-environmental behaviour in aviation as various internal (for example, environmental knowledge) and external (for instance, journey costs) variables determine this transport choice and shape a so-called 'attitude-behaviour gap' in tourist consumption (Barr et al. 2010; Hares et al. 2010; Higham et al. 2014).

Pro-environmental tourist attitudes and behavioural intentions have also been examined in the context of hospitality, where consumer perceptions of the 'greener' tourist accommodation choices and more responsible catering practices have been investigated (Manaktola and Jauhari 2007). Similar to the tourism transport context, research has demonstrated the complex relationship between tourist attitudes, behavioural intentions and 
pro-environmental behaviour in hospitality. Limited environmental knowledge underpins poor consumer recognition of the environmental repercussions of hospitality operations with subsequent negative attitudes (Filimonau et al. 2017). This notwithstanding, some positive correlation has been established between consumer attitudes and the environmental management initiatives implemented in hotels (Han et al. 2010) and restaurants (Namkung and Jang 2013), with consumer willingness to support these on practice, i.e. either by paying a 'green' premium or by engaging in environmental conservation activities (Kang et al. 2012). The higher probability of pro-environmental behavioural intentions to occur in the context of hospitality as compared to tourist transportation can be partly attributed to the lower costs and the fewer efforts that are required to facilitate more responsible behavioural changes in the hospitality context. Indeed, the effort made to re-use towels in hotels is incomparable with a voluntary modal shift to reach a destination.

Existing studies on pro-environmental attitudes and behavioural intentions in tourism have two important shortcomings. First, they have focused on tourists from developed countries given that these account for the largest share of international travel and associated environmental impacts (see, for instance, Gössling et al. 2009; Higham et al. 2016a; Juvan et al. 2016). Although developed countries will remain the mainstay of tourist demand in the foreseeable future (UNWTO 2018), there is a steady growth in outbound tourism in developing and transitional economies. To better understand the potential for environmental mitigation in tourism via voluntary, pro-environmental changes in consumer behaviour, it is critical to identify the determinants of more responsible attitudes and subsequent proenvironmental behavioural intentions among the 'non-western' tourists. Although the research agenda is gradually expanding in this direction (see, for instance, Dillimono and Dickinson 2015; Horng et al. 2014; Tao et al. 2004), more empirical, comparative studies are necessary to inform national policy-making and managerial practice. Second, the majority of 
studies on pro-environmental attitudes and behaviour in tourism have largely excluded the element of national culture from analysis. Although the role of national culture in driving pro-environmental attitudes and subsequent behavioural intentions of tourists has been acknowledged (see, for instance, Campos-Soria et al. 2018; Lee and Jan, 2015; Zhang et al. 2014), this effect has never been tested empirically through the lens of specific cultural frameworks. Yet, national culture holds substantial potential to affect consumer choice and may represent a major driver of travel decisions (Reisinger and Crotts 2009). It should be more carefully investigated to better understand its effect on pro-environmental attitudes and subsequent behaviour in tourism.

\section{The national culture effect}

Within the complexity of psychological variables affecting tourist attitudes, national culture may represent a cornerstone of tourist decision-making (Woodside et al. 2011). The definition of national culture by Hofstede is the most widely cited in cultural studies (Jones 2007). It suggests that national culture represents 'the collective programming of the mind which distinguishes the members of one group or category of people from others' (Hofstede 2003, p.5). Although the effect of national culture on tourist motivation ( $\mathrm{Ng}$ and Soutar 2007), destination choice (Seddighi et al. 2001), purchasing intentions (Money and Crotts 2003) and structure of travel groups (Filimonau and Perez 2018) has been investigated, the research agenda remains non-systematic (Ahn and McKercher 2015). Further, the role of national culture in shaping tourist attitudes has been overlooked in many contexts of tourism academic research, especially from the viewpoint of empirical investigation (Kozak 2002). This signifies a crucial knowledge gap given the significant implications of this topic for tourism planning, marketing, management and policy-making (Lam and Hsu 2006).

Pro-environmental attitudes and behavioural intentions represent one of the research contexts in tourism where studies on the role of national culture are rare (Nejati et al. 2015). 
In their seminal work, Hudson and Ritchie (2001) explored public attitudes to the environment among international skiers. Kang and Moscardo (2006) investigated consumer attitudes to responsible holidaying behaviour among the representatives of three cultural backgrounds. Weeden (2011) studied the effect of culture on ethical consumption in tourism. Landauer et al. (2013) looked at the culture-imposed variations in tourist preferences for climate change adaptation strategies. Lastly, a more recent study by Kim and Filimonau (2017) examined the role of language, as a cognitive element of national culture, in driving pro-environmental attitudes in tourism. Correlation between the cultural background of tourists and their pro-environmental attitudes has been established in the literature which underlines the importance of this topic and emphasises the need for future, in-depth investigation.

\section{Cultural dimensions and pro-environmental attitudes}

A number of cultural frameworks (see, for example, the seminal works by Hofstede 1980; Lewis 2006; Schwartz 1999; Trompenaars and Hampden-Turner 1997) have been developed to aid in understanding of how the core attributes of specific national cultures can affect consumer behaviour. The merit of these cultural frameworks has been validated in various consumption contexts, including tourism (see, for example, Lam and Hsu 2006; Yang and Wong 2012; You et al. 2000). Cultural frameworks are underpinned by particular cultural dimensions or cultural value orientations that enable generalisations and facilitate cross-cultural analysis (Magnusson et al. 2008).

It is important to differentiate between the notions of cultural dimensions and cultural value orientations. Cultural dimensions were first proposed by Hofstede (1980) and then utilised by Trompenaars and Hampden-Turner (1997) in an attempt to identify a set of common cultural values that can prescribe human behaviour. An alternative theory of cultural value orientations was suggested by Kluckhohn and Strodtbeck (1961) and subsequently 
examined empirically by Schwartz $(1999 ; 2006)$. The key difference between these theories is in that the cultural value orientation approach has an individual at the core of analysis, implying that each consumer assigns a different value to a specific phenomenon and this value is based on their personal preferences and orientations that are underpinned by the individual's cultural norms and beliefs. In contrast, theories proposed by Hofstede and Trompenaars and Hampden-Turner utilise the self-developed cultural dimensions as a starting point of analysis, suggesting that these are common across consumers from specific national cultures. In other words, the cultural value orientation approach applies a bottom-up perspective when examining the role of national culture in consumption while Hofstede and Trompenaars and Hampden-Turner adopt the top-down viewpoint. The number of studies underpinned by the cultural value orientation approach in examining the national culture effect on tourist consumption is growing (see, for example, Nath et al. 2016 and Watkins and Gnoth 2011), also in the context of pro-environmental attitudes and pro-environmental behavioural intentions in tourism (see, for instance, Landauer et al. 2013 and Paudyal et al. 2015) while the cultural dimensions of Hofstede and Trompenaars and Hampden-Turner are equally, if not more, popular (Watkins and Gnoth 2011). Most importantly, empirical research has shown that both the cultural dimensions and the cultural value orientations often overlap suggesting that, conceptually, all cultural frameworks are the same (Taras et al. 2009).

There are a number of cultural dimensions/value orientations in existing cultural frameworks that can explain public attitudes towards the environment (Namkung and Jang 2013). The Individualism/Collectivism dimension by Hofstede (1980) or similar Individualism/Communitarianism dimension by Trompenaars and Hampden-Turner (1997) implies that collectivistic cultures are more likely to demonstrate pro-environmental attitudes and pro-environmental behavioural intentions than individualistic cultures. This is because 
the environment is viewed as a 'common commodity' which every member of a collectivistic culture should have equal access to and look after (Collins et al. 2007). Pro-environmental values are therefore best reflected in the collectivistic cultural realm (Tarkiainen and Sundqvist 2009). Next, the Long-term/Short-term orientation dimension by Hofstede (1980), which deals with the time perspective, suggests that long-term orientated cultures should exemplify higher pro-environmental attitudes compared to short-term orientated cultures. This is because most of environmental impacts (for example, climate change) will occur in the future (Rossello-Nadal 2014) and, hence, long-term orientated cultures should be more concerned about the future repercussions of their activities, such as flying with holidaying purposes. Lastly, the Harmony/Mastery dimension/value orientation by Schwartz (1999) or the similar Internal/External Direction dimension by Trompenaars and Hampden-Turner (1997) enables understanding of how national cultures consider the environment in terms of its management. While Harmony-aligned national cultures are pro-social and tend to view the environment as an integral element of their day-to-day lives which should not be controlled, exploited or modified, Mastery-aligned national cultures are self-focussed and perceive the environment as a functional tool to achieve individual aims and facilitate personal growth, thus justifying the need for its control (Hedlund-de Witt et al. 2014). Surprisingly, no research has been undertaken to date to examine the role of these cultural dimensions in shaping pro-environmental attitudes and subsequent behavioural intentions in tourism.

\section{Knowledge gap}

Although the importance of studying the relationship between national culture and proenvironmental attitudes has been recognised, no comprehensive analysis has been undertaken on how specific cultural dimensions could become the determinants of pro-environmental attitudes and subsequent more responsible behaviour in tourism. The geographical scope of existing cultural analysis has further been limited to English-speaking countries (Li 2014). 
This paper contributes to knowledge by expanding the scope of national culture research in tourism towards Poland, a growing tourist market in East-Central Europe. The environmental repercussions of tourism growth in Poland ought to be mitigated while better understanding of the role of national culture in shaping pro-environmental attitudes and behavioural intentions of tourists should aid in developing more effective mitigation measures. To this end, the paper explores the effect of national culture on pro-environmental attitudes of Polish tourists by employing the three cultural dimensions/value orientations proposed by Hofstede (1980), Schwartz (1999) and Trompenaars and Hampden-Turner (1997) that can affect proenvironmental attitudes, as per above.

\section{Tourism in Poland}

The socio-demographic, psychological and behavioural profile of consumers can influence their attitudes to the environment and, subsequently, affect their pro-environmental behaviour (Laroche et al. 2001). Likewise, the settings where consumption takes place can influence consumer perceptions and shape specific behavioural patterns (Miao and Wei 2013). For example, in nature tourism destinations tourists are more likely to have positive attitudes to the environment and actively engage in environmental conservation activities (Halpenny 2010). This is as opposed to mass tourism destinations where consumer perception of and willingness to contrite to environmental conservation can be less pronounced (Oom do Valle et al. 2012). This underlines the importance of better understanding and contextualising tourism in Poland, especially in relation to identifying prospective drivers of proenvironmental attitudes among Polish tourists.

Since late 1990s, Poland has been playing an increasingly important role in the European tourism market. In terms of inbound tourism, with its about 17.5 million international tourist arrivals, Poland was the sixth most popular destination in Europe in 2016 (UNWTO 2017). The majority of tourists (circa 76\%) came from other EU countries, where 
Germany was the leading market (Ministry of Sport and Tourism of the Republic of Poland 2017). The size of the outbound tourism market in Poland was estimated at circa 11.3 million in 2016 which indicates a growth of $11 \%$ since 2012 (Central Statistical Office 2017a). Germany is the most popular destination with Polish tourists due to its proximity (Central Statistical Office 2017a) followed by the UK which is an important market for Polish labour migrants (Filimonau and Mika 2017). Mass tourism destinations in the Mediterranean countries (Portugal, Spain, Italy and Greece) represent another mainstay of outbound tourism demand in Poland and the number of long-haul trips to East Asia and Americas is gradually increasing (Central Statistical Office 2017a). Further, domestic tourism has traditionally been popular in Poland with 43.5 million trips recorded in 2016 (Ministry of Sport and Tourism of the Republic of Poland 2017). Seaside destinations in the north of the country and mountain destinations in the south prevail among domestic tourists in Poland.

Typical tourist behaviour in Poland largely replicates typical tourist behaviour in countries of Western Europe a decade ago. It is characterised by mass consumption where service standards and price represent the determinants of consumer choice (Mika 2014). Although the levels of public environmental awareness in Poland are gradually increasing, consumer knowledge of tourism's environmental impacts and consumer attitudes to the need of their minimisation remain low (Dickinson et al. 2013). Promotion of sustainable consumption patterns in Polish tourism therefore represents a real challenge and joint efforts of all national stakeholders are necessary to achieve meaningful changes (Mika 2014).

\section{Research design}

\section{Study case and data collection}

The study collected data from a sample of Polish tourists in Krakow (Malopolska region). Krakow was selected as a data collection destination because it is the second largest 
city in Poland, hosting the second busiest airport and attracting the largest number of tourists in the country (Central Statistical Office 2015). According to statistical data from Malopolska Tourist Organisation (MTO 2018), in 2017 Krakow hosted 12.8 million tourists where 9.8 million were domestic and 3 million - international. This suggests that Krakow holds circa 23\% of all domestic (Ministry of Sport and Tourism of the Republic of Poland 2017) and about $27 \%$ of all international (Central Statistical Office 2017a) tourism market in Poland.

For data collection, the study utilised a self-completion survey technique which was administered face-to-face in popular public places of Krakow within the period of JuneSeptember 2016. A non-probability sampling strategy on a 'next-to-pass' basis was utilised. The response rate was circa $60 \%$ which is in line with other studies of public opinion in tourism conducted in the Polish context (Dickinson et al. 2013).

Despite the application of a non-probability sampling strategy, the profile of the sample collected $(n=454)$ was well-structured and broadly representative of the Polish population (Table 1). Although the sample contained a substantial number of students (21.8\%) aged 1624 , it is the nature of the national education system in Poland that most students in this country (and many other countries in East-Central Europe) are aged at 19-25. Most of the younger respondents aged below 19 within the sample were in the category of 'Other' in terms of 'Occupation' and 'Level of education'. The sample contained $47.1 \%$ respondents with the personal salary below the nation's average (Table 1). This is in line with national statistics pointing that about $50 \%$ of salaries across Poland in 2016 were below the nation's average (Central Statistical Office 2016). 35.5\% of respondents in the sample finished secondary school (Table 1), which is also in line with national statistics indicating that $36.8 \%$ of the Polish population completed secondary education (Central Statistical Office 2017b). The only noticeable discrepancy between the achieved sample and national statistics was in terms of the number of respondents who were University degree holders and above. There are 
$43.4 \%$ of such respondents in the sample (Table 1) while national statistics report $29.1 \%$ (Central Statistical Office 2017b). This is attributed to the fact that primary data were collected in the academic city of Krakow which hosts a large number of institutions of higher education. Similar sample limitation was reported in Dickinson et al. (2013) who collected primary survey data in Krakow.

[Insert Table 1 here]

\section{Questionnaire design}

The titerature review informed design of the survey questionnaire. Questions were developed in Polish based on the outcome of a small-scale quantitative study piloted in English in the UK. To ensure fluency in Polish language, the back-translation technique was utilised as prescribed by Brislin (1970). Back translation was performed by two bilingual academics and tested on a handful of willing subjects in Poland.

Questions were organised in three main sections. Section 1 (7 statements) aimed at establishing the level of public understanding of the inter-linkages between tourism and environmental impacts in Poland, most notably in the context of aviation and climate change. Section 2 (8 statements) strove to examine perceptions of Polish tourists of the need to mitigate the environmental repercussions of their holidays, including the role of individual actions and actions of other tourism stakeholders, such as national governments and industry representatives. This section also included 2 items that were designed to measure consumer willingness to modify their holidaying behaviour so that it becomes more environmentally responsible. Section 3 (10 statements) employed questions derived from the three, environment-related cultural dimensions/value orientations of major cultural frameworks (Hofstede 1980; Schwartz 1999; Trompenaars and Hampden-Turner 1997) to understand the role of national culture in shaping pro-environmental attitudes and subsequent behavioural intentions of Polish tourists (Table 2). More specifically, the questions were built on the 
following dimensions: Individualism/Collectivism whose score of 60 for Poland indicates that it is a rather individualistic society with subsequent lower pro-environmental attitudes (Hofstede Centre 2017); Long-term/Short-term orientation whose scope of 38 for Poland pinpoints a short-term orientated society characterised by lower pro-environmental attitudes (Hofstede Centre 2017); and Harmony/Mastery whose score of circa 0.83 for Poland suggests that it is a Harmony-aligned nation with consequent higher pro-environmental attitudes (Schwartz 2006). Questions in Sections 1-3 were operationalised using the attitudinal, 5-point Likert rating scale ranging from strongly agree (1) to strongly disagree (5). Additional items collected basic socio-demographic information, including recent travel patterns with holidaying reasons. The survey data were processed and analysed using SPSS Statistics 23.0.

[Insert Table 2 here]

\section{Data analysis technique}

To better understand the role of national culture in shaping pro-environmental attitudes of Polish tourists, Structural Equation Modeling based on Partial Least Squares (SEM-PLS) was selected for data analysis. SEM-PLS is a variance-based, distribution-independent technique suitable for structural equation modeling in the context of high complexity with limited theoretical support and development (Reinartz et al. 2009). This statistical technique is appropriate for exploratory and predictive purposes when attempting to identify new, potential causal relationships and when the measurement instruments are not yet properly formed (Roldan and Sánchez-Franco 2012). Hence, structural equation modeling based on PLS represents an adequate research technique for this study given its exploratory nature.

\section{Data analysis}

Preliminary factor analysis of pro-environmental attitudes 
As a preliminary step, principal component analysis was performed to identify the underlying dimensions of pro-environmental attitudes. It was supplemented with exploratory factor analysis (EFA) which delineated patterns of factors underpinning pro-environmental attitudes of Polish tourists. This is to create a structural model in PLS composed of valid and reliable latent variables. Importantly, factor analysis was not applied to the dimensions of national culture as these have been sufficiently analysed and validated in previous studies, also in tourism (see, for example, Magnusson et al. 2008; Reisinger and Crotts 2009; Soares et al. 2007). Varimax orthogonal rotation was used to obtain the rotated factors. The KaiserMeyer-Olkin (KMO) index and the Bartlett's sphericity test supported the factorability of the correlation matrix (Table 3). Table 3 shows the structure matrix of these constructs after carrying out a varimax orthogonal rotation. Items with low factorial loadings $(<0.5)$ were removed from EFA and not displayed in the table.

[Insert Table 3 here]

The rotated solutions (Table 3) revealed the presence of four factors underlying proenvironmental attitudes of Polish tourists. Interpretation of these factors is as follows. Factor 1 holds the four items that exemplify negative tourist attitudes towards environmental conservation. Here, Polish tourists consider climate change a natural phenomenon which they have no responsibility for and whose magnitude has been exaggerated. Hence, this factor was named Anti-Environmental Attitudes (AEA). Higher scores in this factor indicated less favourable tourist attitudes towards the need to protect the environment. Factor 2 covered the two items related to day-to-day environmental behaviour of tourists and tested consumer knowledge about the problem of climate change. Higher scores in this factor indicated better tourist knowledge about climate change and higher intentions to demonstrate more responsible, pro-environmental behaviour in daily life. This factor was named Personal Environmental Interest (PEI). Factor 3 included the four items that measured tourist 
perceptions of the environmental impacts attributed to tourism in general, and their specific sectors and individual tourist behaviour in particular. Higher scores in this factor indicated higher tourist concern about the negative environmental repercussions of tourism. This factor was labeled Tourism Environmental Impact (TEI). Lastly, factor 4 clustered the two items on tourist perceptions of the role of national governments and commercial tourism operators in minimising the environmental footprint of tourism. Higher scores in this factor indicated higher expectations of the government and industry engagement in mitigating the negative environmental impacts of tourism operations. This factor was named Public and Private Environmental Responsibility (PPER).

Table 4 provides descriptive statistics for the variables that measured the relationship between the dimensions of national culture and behavioural intentions. It should be noted that, in order to operationalise these constructs and incorporate these in the structural equation model, the items had to be re-coded to direct the variables. Consequently, these latent variables were operationalised as the broad dimensions of the different national cultural traits related to pro-environmental attitudes. The higher scores of the IndividualismCollectivism variable indicated the stronger Individualism trait. Specifically, this construct reflected the individual's concern of the negative effect imposed by their behaviour on the environment. The higher scores of the (Short/Long term) Orientation variable indicated longer-term orientation. This variable captured the individual's perception of the effect imposed by their behaviour on the future state of the environment. The higher scores of the Harmony-Mastery variable pinpointed a higher harmony-aligned culture. This construct dealt with the individual's consideration of the primacy of the environment over the human goals and the role of humanity in minimising negative environmental impacts. Lastly, the higher scores of tourist behavioral intentions (TBI) indicated stronger willingness to modify travel behavior to make it more environment-benign. 
[Insert Table 4 here]

\section{Evaluation of the SEM-PLS model}

To analyse the effect of national culture on pro-environmental attitudes and subsequent behavioral intentions of Polish tourists, a PLS-based model was constructed. The specific SEM literature indicates two stages for this analysis (Gefen et al. 2000). First, the assessment of the measurement or the outer model should be conducted. This model attempts to analyse if the theoretical constructs are correctly measured by the study's measures. Second, the evaluation of the structural or the inner model should be undertaken. The structural model evaluates the significance, the magnitude and the sign of the structural model's relationships between the latent variables. In the structural equation model, the three national cultural dimensions/value orientations utilised in this study were considered the antecedents of pro-environmental attitudes while these pro-environmental attitudes were subsequently viewed as the predictors of environmentally responsible behavioral intentions of Polish tourists. Figure 1 presents the conceptual model adopted in this study.

[Insert Figure 1 here]

\section{Assessment of the measurement model}

To assess the suitability of the measurement model, the latent variables' individual reliability, composite reliability and convergent and discriminant validity were first examined. In this initial assessment composite reliability (CR) and convergent validity were not met as the CR index and the average variance extracted (AVE) value of the Individualism-Collectivism and Harmony-Mastery variables fell below the critical thresholds. More specifically, items IND4 $(\lambda=0.598), \operatorname{HARM} 3(\lambda=0.419)$ and HARM4 $(\lambda=0.176)$ (Table 4) showed very reduced individual factor loadings for their respective latent variables. These items were therefore removed from the model and the re-assessment was held whose 
outcome is presented in Table 5. Here, individual reliability was confirmed as, for most of the items, the outer loadings on their respective latent variables were above the critical threshold of 0.7 (Carmines and Zeller 1979). Although some factorial loadings were slightly below the critical threshold of 0.7 , these were retained in the model to preserve content validity and because the CR and AVE values were acceptable (Hair et al. 2011). In fact, the CR values were above the critical threshold of 0.7 and the AVE values were all above, or close to, 0.5 . This demonstrated composite reliability and convergent validity of the model. Lastly, discriminant validity was verified using the Fornell and Larcker (1981) criterion. This enabled comparison of the squared root of the latent variables' AVE values with the correlations of the every pair of variables in the model. Table 6 reports the results of analysis and verifies that latent variables share more common variance with the assigned indicators than with any other indicators in the model, thus accepting discriminant validity.

[Insert Table 5 here]

[Insert Table 6 here]

\section{Assessment of the structural model}

After the validation of the measurement model, the structural model was assessed to establish significance of the path coefficients. To this end, a bootstrapping procedure with 5.000 subsamples was employed. The bootstrapping technique is a common nonparametric test of resampling in PLS (Hair et al. 2011). The model explained 22.9\% of AEA, $27.2 \%$ of PEI, $11.4 \%$ of TEI, of $11.8 \%$ PPER and $25.8 \%$ of TBI variance. A Stone-Geisser test was also performed to verify the existence of predictive relevance. The results suggested that predictive relevance was met since all the $Q^{2}$ values were positive. Table 7 presents the outcome of the resultant structural model.

[Insert Table 7 here] 


\section{Interpretation of results}

The analysis demonstrated that the higher scores of Individualism demonstrated by the majority of Polish tourists were positively and significantly related to Anti-Environmental Attitudes $(\beta=0.200 ; \mathrm{t}=3.486)$ and negatively and significantly connected to Personal Environmental Interest $(\beta=0.200 ; \mathrm{t}=3.486)$. However, this variable was not a significant predictor of tourist perceptions of the environmental impacts of tourism $(\beta=-0.084 ; t=1.200)$ and of the role of public and private tourism enterprises in mitigating the environmental problems of tourism $(\beta=0.010 ; \mathrm{t}=0.865)$. In other words, the results revealed that the higher scores of Collectivism were well correlated with a stronger concern among Polish tourists of the environmental footprint of holidaymaking and a stronger willingness to modify individual tourist behaviour to make it more environmentally responsible.

For the Long-term orientation dimension, analysis showed that Long-term orientation was negatively and significantly associated with Anti-Environmental Attitudes $(\beta=-0.201$; $\mathrm{t}=3.687$ ) and positively related to tourist perceptions of the environmental impacts of tourism $(\beta=0.283 ; \mathrm{t}=4.872)$ in Poland. This variable was further positively, but not significantly, correlated with Personal Environmental Interest $(\beta=0.057$; $\mathrm{t}=0.976)$ and perceptions of the role of national governments and private tourism operators in minimising the magnitude of the environmental impacts from tourism $(\beta=0.081 ; \mathrm{t}=1.239)$. In other words, the higher scores on the Long-term orientation dimension determined more favourable environmental attitudes among Polish tourists with further potential willingness to change individual holidaying behaviour to make it more environmentally responsible.

The model revealed that the higher scores on the Harmony-Alignment dimension/value orientation demonstrated by Polish tourists had a negative impact on Anti-Environmental Attitudes $(\beta=-0.162 ; \mathrm{t}=2.911)$, and a positive and significant impact on Personal Environmental Interest $(\beta=0.219 ; \mathrm{t}=3.532)$ and tourist perceptions of the responsibility of 
public and private tourism enterprises in minimising the environmental problems of tourism $(\beta=0.301 ; \mathrm{t}=4.586)$. However, this variable was not significantly associated with Tourism Environmental Impacts $(\beta=-0.003 ; \mathrm{t}=0.055)$. Thus, analysis suggested that Polish tourists with the higher scores on Harmony would be more inclined to preserve the environment as they demonstrated stronger pro-environmental attitudes. They would still however assign a major role in mitigating the negative environmental repercussions of tourism to national governments and tourism industry representatives, rather than to their individual actions.

Lastly, the model examined how pro-environmental attitudes could affect tourist willingness to modify behaviour to make it more environmentally responsible in Poland. Analysis showed than the Anti-Environmental Attitudes, Personal Environmental Interest and Tourism Environmental Impact dimensions explained tourist intentions to change behavioural patterns. Specifically, Anti-Environmental Attitudes had a negative effect ( $\beta=-$ 0.192; $\mathrm{t}=3.928)$, while Personal Environmental Interest $(\beta=0.245 ; \mathrm{t}=5.163)$ and Tourism Environmental Impact $(\beta=0.290 ; t=5.903)$ exerted a positive effect. Tourist perceptions of the role of national governments and tourism industry representatives did not significantly affect this variable $(\beta=-0.003 ; \mathrm{t}=0.068)$. Figure 2 summarises the model's main findings.

[Insert Figure 2 here]

\section{Discussion}

The study demonstrated the validity of the major cultural frameworks (Hofstede 1980; Schwartz 1999; Trompenaars and Hampden-Turner 1997) as applied in a new context, i.e. to understand the determinants of pro-environmental attitudes in tourism. To-date, national culture has largely been excluded from analysis of the multiple drivers of (more) responsible consumer choice in tourism (Kim and Filimonau 2017). The main contribution of this study is thus in that it has exemplified empirically how certain, environment-orientated 
dimensions/value orientations of national culture could aid in predicting pro-environmental attitudes and subsequent pro-environmental behavioural intentions of tourists. Poland was used as a proxy country for analysis given the foreseen importance of this country as a future tourist market, both in East-Central Europe and globally.

The explicit role of national culture as a determinant of pro-environmental attitudes in tourism can be observed in previous research where, however, its impact has not been testified empirically. Further, the comprehensive literature review conducted as part of this project has identified no studies that would utilise the cultural dimensions/value orientations proposed by Hofstede, Schwartz and Trompenaars and Hampden-Turner to capture the effect of national culture on pro-environmental attitudes and subsequent behavioural intentions of tourists. For instance, there have been seminal attempts to examine pro-environmental attitudes of tourists in the UK (Hares et al. 2010), Norway (Higham and Cohen 2011), New Zealand (Becken 2007) and Australia (Higham et al. 2016b) with low levels of public proenvironmental attitudes recorded. Similar to Poland, these countries are all individualistic and short-term orientated (Hofstede Centre 2017), which suggests that, aside from various internal and external determinants of pro-environmental attitudes in tourism, national culture may have had an important role to play and should have been elaborated upon in more detail in the above seminal studies. This also holds true for the study by Dickinson et al. (2013) which has examined public perceptions of the environmental impacts of tourism in Poland but excluded the element of national culture from analysis. Dickinson et al. (2013) have found external factors, such as social norms and peer pressure, to be the prime barriers towards the adoption of voluntary, pro-environmental behavioural changes among Polish tourists while the outcome of this study suggests that internal factors, such as national culture, may have imposed an equally important barrier. To gain a more holistic and accurate account of the determinants of more responsible consumer choice in tourism and to develop more 
effective policy-making and managerial interventions to mitigate the negative repercussions of tourist behaviour on the environment, it is thus important to execute the analysis of both internal and external drivers of tourist attitudes and behavioural intentions.

This study has thus reinforced evidence as to why national culture should become an integral element of tourism research (Crotts and Erdmann 2002), especially when striving to understand the drivers of pro-environmental attitudes and behavioural intentions among tourists. National culture should also be accounted for by policy-makers and managers when designing environmental mitigation measures in tourism. For example, as shown in this study, Polish tourists tend to delegate environmental mitigation to other tourism stakeholders, i.e. national government and tourism businesses. This may be partially attributed to the strong Individualism trait, where personal interests are prioritised over the 'common commodity', which has been found pronounced for the Polish culture. This may suggest that, due to the national cultural background, voluntary behavioural changes are unlikely to become an effective, stand-alone environmental mitigation instrument in Polish tourism in the shortterm. Education as a cultural representation of any nation can be utilised to gradually enhance pro-environmental attitudes of Polish tourists, but is only considered feasible as a long-term solution (Becken 2004). Hence, short-term mitigation can only be achieved in Polish tourism when voluntary behavioural changes are supplemented with those environmental mitigation measures that require little individual effort, such as technological innovations and regulatory interventions. This is confirmed by Dickinson et al. (2013) whose study on proenvironmental perceptions of tourists was conducted in the Polish context but excluded the effect of national culture from analysis. Importantly, this finding holds true for other geographies, where the traits of Individualism are strong, and where tourists have failed to consider environmental mitigation as an individual responsibility, but to rather assign it to 
various external actors (Higham et al. 2016b; McKercher et al. 2010; Reis and Higham 2017).

Lastly, this study found that, next to national culture, the level of public environmental knowledge in Poland exerts a positive effect on pro-environmental attitudes and proenvironmental behavioural intentions in tourism. This finding contradicts some of previous research (see, for example, Becken 2007; Cohen and Higham 2011; Hares et al. 2010) as it indicates correlation between better knowledge of the environmental impacts of tourism and more environmentally responsible behavioural intentions among Polish tourists. It should however be noticed that most of the previous research on the inter-linkages between public environmental knowledge and pro-environmental behaviour in tourism has been conducted in the context of developed countries and through a lens of the qualitative research paradigm. Qualitative research enables more in-depth investigation of such complex societal phenomena in established consumption markets as public pro-environmental attitudes and may have therefore revealed additional, internal and external, factors that have potential to offset the profound effect of national culture on shaping pro-environmental attitudes of tourists.

\section{Conclusions}

Although the important role of national culture in driving consumer attitudes and subsequent behavioural intentions in tourism has long been recognised, there is a paucity of empirical research aiming to demonstrate the effect of national culture on tourist attitudes and behaviour in real life settings. The scope of existing studies has been restricted, with such important areas as pro-environmental consumption patterns of tourists being completely overlooked. The geographical scale of research has further been limited and the emerging tourist markets have been excluded from analysis. 
This study contributed to knowledge by exploring how specific, environment-related dimensions/value orientations of major cultural frameworks influence pro-environmental attitudes and behavioural intentions of Polish tourists. It demonstrated the mediating effect of national culture on shaping consumer attitudes to tourism's environmental impacts alongside potential mitigation approaches, thus extending evidence of the applicability of major cultural theories to the domain of sustainable tourism. Correlation was found between the main cultural traits of Polish tourists and the levels of public environmental interest and potential engagement in environmental mitigation practices in tourism, thus underlining a number of policy-making, managerial and research implications.

In particular, the outcome of this study indicated that, in a short-term perspective, tourism policy-makers and practitioners in Poland should aim at developing mitigation measures with a lesser focus on voluntary behavioural changes. The pronounced traits of Individualism and Short-term orientation in the Polish culture suggest low probability of the prompt adoption of voluntary changes in individual consumer behaviour. Assigning responsibility to external stakeholders is seen by Polish tourists as a more feasible means to reduce the environmental significance of tourism. Educating Polish consumers about the environmental repercussions of their travel decisions has potential to enhance proenvironmental attitudes of tourists, thus leading to more responsible behavioural intentions in the future. Specifically, the educational interventions can strive to enhance the Harmony trait of the Polish culture and, yet, the tangible effect of these interventions is most likely to be observed in a long-term perspective given the lengthy and complex process of national culture's transformations.

The main limitation of the study's outcome is in that it only applies to the analysis of tourists representing countries with fairly homogeneous national culture compositions, such as Poland. The growth in migration at a global scale suggests that the cultural background of 
tourists can no longer be defined on the basis of their source country. It is therefore important to understand the cultural background of tourists, rather than a country of their origin, prior to replicating this study in other consumption contexts.

Future research should also aim at strengthening empirical evidence collected in the current study on the role of national culture in shaping pro-environmental attitudes in tourism. Explorations of other national cultures should be undertaken in various political and socio-economic contexts and a cross-cultural analysis should be performed to validate the outcome of this exploratory project. The effect of specific cultural traits (for example, Individualism/Collectivism) on pro-environmental tourist attitudes should be an object of more in-depth examination while the feasibility of integrating other cultural frameworks in analysis, especially those with less pronounced environmental dimensions (such as Lewis 2006), should be carefully investigated. Given the broad nature of the factors obtained in the exploratory factor analysis of this study, more specific and narrower dimensions/value orientations of natural culture should be adopted when studying its role in shaping proenvironmental tourist attitudes and subsequent behaviour. For example, Singelis et al. (1995) differentiate between the vertical, i.e. emphasising personal preference for societal hierarchy, and horizontal, i.e. valuing equality in societies, traits of Individualism/Collectivism. This distinction in the measurement of the effect of national culture is more specific and may therefore contribute to better understanding of how these cultural traits affect proenvironmental attitudes and behavioural intentions in tourism. This is because such a horizontal versus vertical distinction is better suited conceptually to examine the role of personal values, such as power, achievement, self-direction and/or conformity. Likewise, the use of the bi-dimensional conceptualisation of Short/Long term orientation as proposed by Bearden et al. (2006) would enable future studies to gain an in-depth insight into how tourists from Long-term orientated national cultures can potentially exhibit more pronounced pro- 
environmental attitudes. Better understanding of the effect exerted by these more specific / narrower dimensions of national culture should be undertaken via confirmatory, rather than exploratory, research. 


\section{References}

Ahn, M., and McKercher, B., 2015. The Effect of Cultural Distance on Tourism: A Study of International Visitors to Hong Kong. Asia Pacific Journal of Tourism Research, 20(1), 94113.

Ajzen, I., and Driver, B.L., 1991. Prediction of leisure participation from behavioural, normative and control beliefs: an application of the theory of planned behaviour. Leisure Sciences, 13(3), 185-204.

Ajzen, I., and Fishbein, M., 1980. Understanding attitudes and predicting social behaviour. Englewood Cliffs, Prentice Hall.

Barr, S., Shaw, G., Colies, T., and Prillwitz, J., 2010. 'A holiday is a holiday': practicing sustainability, home and away. Journal of Transport Geography, 18(3), 474-481.

Bearden, W.O., Money, R.B., and Nevins, J.L., 2006. A measure of long-term orientation: Development and validation. Journal of the Academy of Marketing Science, 34(3), 456-467.

Becken, S., 2004. How Tourists and Tourism Experts Perceive Climate Change and Carbonoffsetting Schemes. Journal of Sustainable Tourism, 12(4), 332-345.

Becken, S., 2007. Tourists' Perception of International Air Travel's Impact on the Global Climate and Potential Climate Change Policies. Journal of Sustainable Tourism, 15(4), 351368.

Bowen, D., and Clarke, J., 2009. Contemporary tourist behaviour: yourself and others as tourists. Wallingford: CABI.

Brislin, R.W. 1970. Back-Translation for Cross-Cultural Research. Journal of Cross-Cultural Psychology, 1, 185-216. 
Budeanu, A., 2007. Sustainable tourist behaviour-a discussion of opportunities for change. International Journal of Consumer Studies, 31(5), 499-508.

Campos-Soria, J.A., Garcia-Pozo, A., and Marchante-Mera, A.J., 2018. Explaining touristsattitudes to environmental support: a multilevel approach. Journal of Sustainable Tourism, 26(6), 987-1006.

Carmines, E.G., and Zeller, R.A. 1979. Reliability and validity assessment. Sage Publications, London.

Central Statistical Office, 2016. Struktura wynagrodzeń wedtug zawodów w październiku 2016 r. [Remuneration structure by occupation in October 2016]. Warszawa, 2016. Available from: http://stat.gov.pl/obszary-tematyczne/rynek-pracy/pracujacy-zatrudnieniwynagrodzenia-koszty-pracy/struktura-wynagrodzen-wedlug-zawodow-w-pazdzierniku-

2016-r-,5,5.html\# [Accessed 04 December 2017].

Central Statistical Office, 2017a. Tourism in 2016. Statistical information and elaborations. Warszawa, 2015. Available from: https://stat.gov.pl/download/gfx/portalinformacyjny/pl/defaultaktualnosci/5494/1/14/1/turysty ka_w_2016_zmieniona_07-11-2017.pdf [Accessed 18 June 2018].

Central Statistical Office, 2017b. Demographic Yearbook of Poland 2017. Warszawa, 2017. Available from: $\quad$ https://stat.gov.pl/en/topics/statistical-yearbooks/statisticalyearbooks/demographic-yearbook-of-poland-2017,3,11.html [Accessed 04 December 2017].

Chan, E.S.W., 2008. Barriers to EMS in the hotel industry. International Journal of Hospitality Management, 27(2), 187-196.

Chapman, L., 2007. Transport and climate change: a review. Journal of Transport Geography, 15(5), 354-367. 
Chiu, Y-T.H., Lee, W-I., and Chen, T-H., 2014. Environmentally responsible behavior in ecotourism: Antecedents and implications. Tourism Management, 40, 321-329.

Cohen, S.A., and Higham, J.E.S., 2011. Eyes wide shut? UK consumer perceptions on aviation climate impacts and travel decisions to New Zealand. Current Issues in Tourism, 14(4), 323-335.

Cohen, S.A., Prayag, G. and Moital, M., 2014. Consumer behaviour in tourism: concepts, influences and opportunities. Current Issues in Tourism, 17(10), 872-909.

Collins, C.M., Steg, L., and Koning, M.A.S., 2007. Customers' values, beliefs on sustainable corporate performance, and buying behaviour. Psychology and Marketing, 24, 555-577.

Craig, C.S., and Douglas, S.P., 2006. Beyond national culture: Implications of cultural dynamics for consumer research. International Marketing Review, 23(3), 322-342.

Crotts, J., and Erdmann, R., 2002. Does national culture influence consumers' evaluation of travel services? A test of Hofstede's model of cross-cultural differences. Managing Service Quality, 10(5), 410-419.

Dickinson, J.E., Robbins, D., Filimonau, V., Hares, A., and Mika, M. 2013. Awareness of Tourism Impacts on Climate Change and the Implications for Travel Practice: A Polish Perspective. Journal of Travel Research, 52, 506-519.

Dillimono, H.D., and Dickinson, J.E., 2015. Travel, tourism, climate change, and behavioral change: travelers' perspectives from a developing country, Nigeria. Journal of Sustainable Tourism, 23(3), 437-454.

Dolnicar, S., Crouch, G.I., and Long, P., 2008. Environment-friendly Tourists: What Do We Really Know About Them? Journal of Sustainable Tourism, 16(2), 197-210. 
Filimonau, V., and Högström, M., 2017. The attitudes of UK tourists to the use of biofuels in civil aviation: An exploratory study. Journal of Air Transport Management, 63, 84-94.

Filimonau, V., and Mika, M., 2017. Return labour migration: an exploratory study of Polish migrant workers from the UK hospitality industry. Current Issues in Tourism, iFirst, https://doi.org/10.1080/13683500.2017.1280778

Filimonau, V., and Perez, L., 2018. National culture and tourist destination choice in the UK and Venezuela. Tourism Geographies, in press. DOI: 10.1080/14616688.2018.1490342

Filimonau, V., Lemmer, C., Marshall, D., and Bejjani, G., 2017. 'Nudging' as an architect of more responsible consumer choice in food service provision: The role of restaurant menu design. Journal of Cleaner Production, 144, 161-170.

Fornell, C., and Larcker, D.F., 1981. Structural equation models with unobservable variables and measurement error: Algebra and statistics. Journal of Marketing Research, 18(3), 382388.

Gefen, D., Straub, D., and Boudreau, M.C., 2000. Structural equation modeling and regression: Guidelines for research practice. Communications of the association for information systems, 4(1), 7.

Gonda, M., 2006. National and Ethnic Minorities in Poland According to the Census of 2002 and its Influence on the Polish Legislation Concerning Minorities. University of Lodz. Available $\quad$ from: $\quad$ https://eltalpykla.vdu.lt/bitstream/handle/1/32662/ISSN20292074_2006_V_1.PG_65_80.pdf?sequence=1\&isAllowed=y [Accessed 18 June 2018].

Gössling, S., 2002. Global environmental consequences of tourism. Global Environmental Change, 12(4), 283-302. 
Gössling, S., 2015. New performance indicators for water management in tourism. Tourism Management, 46, 233-244.

Gössling, S., and Hall, C.M., 2006. Uncertainties in predicting tourist travel flows under scenarios of climate change. Climate Change, 79(3-4), 163-173.

Gössling, S., and Peeters, P., 2015. Assessing tourism's global environmental impact 19002050. Journal of Sustainable Tourism, 23(5), 639-659.

Gössling, S., Haglund, L., Kallgren, H., Revahl, M., and Hultman, J., 2009. Swedish air travellers and voluntary carbon offsets: Towards the co-creation of environmental value? Current Issues in Tourism, 12(1), 1-19.

Gössling, S., Scott, D., Hall, C.M., Ceron, J.-P., Dubois, G., 2012. Consumer behaviour and demand response of tourists to climate change. Annals of Tourism Research, 39(1), 36-58.

Hair, J.F., Ringle, C.M., and Sarstedt, M. 2011. PLS-SEM: Indeed a silver bullet. Journal of Marketing Theory and Practice, 19(2), 139-152.

Hall, C.M., 2013. Framing behavioural approaches to understanding and governing sustainable tourism consumption: beyond neoliberalism, "nudging" and "green growth"? Journal of Sustainable Tourism, 21(7), 1091-1109.

Halpenny, E.A., 2010. Pro-environmental behaviours and park visitors: The effect of place attachment. Journal of Environmental Psychology, 30(4), 409-421.

Han, H., Hsu, L-T., and Sheu, C., 2010. Application of the Theory of Planned Behavior to green hotel choice: Testing the effect of environmental friendly activities. Tourism Management, 31(3), 325-334.

Hares, A., Dickinson, J., and Wilkes, K., 2010. Climate change and the air travel decisions of UK tourists. Journal of Transport Geography, 18(3), 466-473. 
Hedlund-de Witt, A., de Boer, J., and Boersema, J.J., 2014. Exploring inner and outer worlds: A quantitative study of worldviews, environmental attitudes, and sustainable lifestyles. Journal of Environmental Psychology, 37, 40-54.

Higham, J.E.S., and Cohen, S.A., 2011. Canary in the coalmine: Norwegian attitudes towards climate change and extreme long-haul air travel to Aotearoa/New Zealand. Tourism Management, 32(1), 98-105.

Higham, J.E.S., Cohen, S.A., and Cavaliere, C.T., 2014. Climate Change, Discretionary Air Travel, and the "Flyers' Dilemma". Journal of Travel Research, 53(4), 462-475.

Higham, J.E.S., Reis, A., and Cohen, S.A., 2016a. Australian climate concern and the ‘attitude-behaviour gap'. Current Issues in Tourism, 19(4), 338-354.

Higham, J.E.S., Cohen, S.A., Cavaliere, C.T., Reis, A., and Finkler, W., 2016b. Climate change, tourist air travel and radical emissions reduction. Journal of Cleaner Production, 111(Part B), 336-347.

Hofstede, G., 1980. Culture's consequences: International differences in work-related values. Beverly Hills, CA: Sage.

Hofstede, G., 2003. Cultures and Organizations: Software of the Mind: Intercultural Cooperation and its Importance for Survival. London: Profile Books.

Hofstede Centre, 2017. Poland. Available from: https://geert-hofstede.com/poland.html [Accessed 07 July 2017].

Horng, J-S., Hu, M-L.M., Teng, C-C.C., and Lin, L., 2014. Energy Saving and Carbon Reduction Behaviors in Tourism - A Perception Study of Asian Visitors from a Protection Motivation Theory Perspective. Asia Pacific Journal of Tourism Research, 19(6), 721-735. 
Hudson, S., and Ritchie, J.R.B., 2001. Cross-cultural tourist behaviour: an analysis of tourist attitudes towards the environment. Journal of Travel \& Tourism Marketing, 10(2-3), 1-22.

Jeong, E-H., Jang, S-C., Day, J., and Ha., S., 2014. The impact of eco-friendly practices on green image and customer attitudes: An investigation in a café setting. International Journal of Hospitality Management, 41, 10-20.

Jones, M., 2007. Hofstede-Culturally questionable? Oxford Business \& Economics Conference, Oxford 24-26 June 2007, Oxford, UK: University of Wollongong. Available from: $\quad$ http://ro.uow.edu.au/cgi/viewcontent.cgi?article=1389\&context=commpapers [Accessed 04 December 2017].

Juvan, E., Ring, A., Leisch, F., and Dolnikar, S., 2016. Tourist segments' justifications for behaving in an environmentally unsustainable way. Journal of Sustainable Tourism, 24(11), $1506-1522$.

Kang, M., and Moscardo, G., 2006. Exploring cross-cultural differences in attitudes towards responsible tourist behaviour: a comparison of Korean, British and Australian tourists. Asia Pacific Journal of Tourism Research, 11(4), 303-320.

Kang, K.H., Stein, L., Heo, C.Y., and Lee, S., 2012. Consumers' willingness to pay for green initiatives of the hotel industry. International Journal of Hospitality Management, 31(2), 564572.

Kim, A.K., 2012. Determinants of tourist behaviour in coastal environmental protection. Tourism Geographies, 14(1), 26-49.

Kluckhohn, F.R., and Strodtbeck, F., 1961. Variations in value orientations. Peterson and Company, New York. Kozak, M., 2002. Comparative Analysis of Tourist Motivations by Nationality and Destinations. Tourism Management, 23(1), 221-232. 
Kroesen, M., 2013. Exploring people's viewpoints on air travel and climate change: understanding inconsistencies. Journal of Sustainable Tourism, 21(2), 271-290.

Lam, T., and Hsu, C.H.C., 2006. Predicting Behavioral Intention of Choosing a Travel Destination. Tourism Management, 27(4), 589-599.

Landauer, M., Haider, W., and Proebstl-Haider, U., 2013. The Influence of Culture on Climate Change Adaptation Strategies: Preferences of Cross-Country Skiers in Austria and Finland. Journal of Travel Research, 53(1), 96-110.

Laroche, M., Bergeron, J., and Barbaro-Forleo, G., 2001. Targeting consumers who are willing to pay more for environmentally friendly products. Journal of Consumer Marketing, 18(6), 503-520.

Lee, T.H., and Jan, F-H., 2015. The influence of recreation experience and environmental attitude on the environmentally responsible behavior of community-based tourists in Taiwan. Journal of Sustainable Tourism, 23(7), 1063-1094.

Leonidou, L.C., Coudounaris, D.N., Kvasova, O., Christodoulides, P., 2015. Drivers and outcomes of green tourist attitudes and behaviour: sociodemographic moderating effects. Psychology \& Marketing, 32(6), 635-650.

Lewis, R.D., 2006. When cultures collide: leading across cultures. $3^{\text {rd }}$ edition. Boston: Nicholas Brealey.

Li, M., 2014. Cross-cultural tourist research: a meta-analysis. Journal of Hospitality and Tourism Research, 38(1), 40-77.

Magnusson, P., Wilson, R.T., Zdravkovic, S., Xin Zhou, J., and Westjohn, S.A., 2008. Breaking through the cultural clutter: a comparative assessment of multiple cultural and institutional frameworks. International Marketing Review, 25(2), 183-201. 
Malopolska Tourist Organisation-MTO, 2018. Ruch turystyczny w Krakowie w 2017 [Tourist traffic in Krakow in 2017]. Available from: https://www.bip.krakow.pl/plik.php?zid=199304\&wer=0\&new=t\&mode=shw $[$ Accessed 18 June 2018].

Manaktola, K., and Jauhari, V., 2007. Exploring consumer attitude and behaviour towards green practices in the lodging industry in India. International Journal of Contemporary Hospitality Management, 19(5), 364-377.

Mayo, E.J., and Jarvis, L.P., 1981. The psychology of leisure travel: effective marketing and selling of travel services. Boston: CBI Pub. Co.

McKercher, B., Prideaux, B., Cheung, C., Law, R., 2010. Achieving voluntary reductions in the carbon footprint of tourism and climate change. Journal of Sustainable Tourism, 18, $297-$ 318.

Miao, L., and Wei, W., 2013. Consumers' pro-environmental behavior and the underlying motivations: A comparison between household and hotel settings. International Journal of Hospitality Management, 32, 102-112.

Mika, M., 2014. Assumptions and determinants of sustainability of local tourism development. Report published by the Institute of Geography and Spatial Management, Jagiellonian University. Krakow, Poland.

Ministry of Sport and Tourism of the Republic of Poland, 2017. Turystyka w Polsce 2016 [Tourism in Poland 2016]. Warsaw, Poland, 2017.

Money, R.B., and Crotts, J.C., 2003. The Effect of Uncertainty Avoidance on Information Search, Planning, and Purchases of International Travel Vacations. Tourism Management, 24(2), 191-202. 
Moscardo, G., 2004. East versus West: a useful distinction or misleading myth. Tourism, 52(1), 7-20.

Moutinho, L., 1987. Consumer Behaviour in Tourism. European Journal of Marketing, 21(10), 5-44.

Namkung, Y., and Jang, S.C., 2013. Effects of restaurant green practices on brand equity formation: Do green practices really matter? International Journal of Hospitality Management, 33, 85-95.

Nath, P., Devlin, J., and Reid, V., 2015. Expectation Formation in Case of Newer Hotels. The Role of Advertising, Price, and Culture. Journal of Travel Research, 55(2), 261-275.

Nejati, M., Mohamed, B., and Omar, S.I., 2015. The influence of perceived environmental impacts of tourism on the perceived importance of sustainable tourism. E-Review of Tourism Research, 12(1-2), 99-114.

Ng, S., Lee, J., and Soutar, G., 2007. Tourists' intention to visit a country: The impact of cultural distance. Tourism Management, 28(6), 1497-1506.

Oom do Valle, P., Pintassilgo, P., Matias, A., and Andre, F., 2012. Tourist attitudes towards an accommodation tax earmarked for environmental protection: A survey in the Algarve. Tourism Management, 33(6), 1408-1416.

Paudyal, R., Poudyal, N.C., Bowker, J.M., Dorison, A.M., Zarnoch, S.J., and Green, G.T., 2015. A value orientation approach to assess and compare climate change risk perception among trout anglers in Georgia, USA. Journal of Outdoor Recreation and Tourism, 11, 2233.

Peeters, P., and Dubois, G., 2010. Tourism travel under climate change mitigation constraints. Journal of Transport Geography, 18(3), 447-457. 
Reinartz, W., Haenlein, M., and Henseler, J. 2009. An empirical comparison of the efficacy of covariance-based and variance-based SEM. International Journal of Research in Marketing, 26(4), 332-344.

Reis, A.C., and Higham, J.E.S., 2017. Climate change perceptions among Australian nonfrequent flyers. Tourism Recreation

Reisinger, Y. and Crotts, J., 2009. Applying Hofstede's National Culture Measures in Tourism Research: Illuminating Issues of Divergence and Convergence. Journal of Travel Research, 49(2), 153-164.

Roldan, J.L., and Sanchez-Franco, M.J. 2012. Variance-based structural equation modeling: guidelines for using partial least squares. In MORA, M.: Research methodologies, innovations and philosophies in software systems engineering and information systems, IGI Global.

Rossello-Nadal, J., 2014. How to evaluate the effects of climate change on tourism. Tourism Management, 42, 334-340.

Schwartz, S.H., 1999. A theory of cultural values and some implications for work. Applied Psychology: An International Review, 48(1), 23-47.

Schwartz, S.H., 2006. A theory of cultural value orientations: explications and applications. Comparative Sociology, 5(2), 137-182.

Scott, D., Peeters, P., and Gössling, S., 2010. Can tourism deliver its "aspirational" greenhouse gas emission reduction targets? Journal of Sustainable Tourism, 18(3), 393-408.

Seddighi, H., Nuttall, M., and Theocharous, A., 2001. Does cultural background of tourists influence the destination choice? An empirical study with special reference to political instability. Tourism Management, 22(2), 181-191. 
Singelis, T.M., Triandis, H.C., Bhawuk, D.P., and Gelfand, M.J., 1995. Horizontal and vertical dimensions of individualism and collectivism: A theoretical and measurement refinement. Cross-cultural research, 29(3), 240-275.

Sirakaya, E. and Woodside, A., 2005. Building and Testing Theories of Decision Making by Travellers. Tourism Management, 26(6), 815-832.

Soares, A., Farhangmehr, M., and Shoham, A., 2007. Hofstede's Dimensions of Culture in International Marketing Studies. Journal of Business Research, 60(3), 277-284.

Stern, P.C., 2000. Toward a coherent theory of environmentally significant behavior. Journal of Social Issues, 56(3), 407-424.

Tao, C-H., Eagles, P.F.J., and Smith, S.L.J., 2004. Profiling Taiwanese Ecotourists Using a Self-definition Approach. Journal of Sustainable Tourism, 12(2), 149-168.

Taras, V., Rowney, J., and Steel, P., 2009. Half a Century of Measuring Culture: Approaches, Challenges, Limitations, and Suggestions Based on the Analysis of 121 Instruments for Quantifying Culture. Journal of International Management, 15(4), 357-373.

Tarkiainen, A., and Sundqvist, S., 2009. Product involvement in organic food consumption: does ideology meet practice? Psychology and Marketing, 26(9), 844-863.

Trompenaars, F., and Hampden-Turner, C., 1997. Riding the waves of culture: understanding cultural diversity in business. London: Nicholas Brealey.

Trung, D.N., and Kumar, S., 2005. Resource use and waste management in Vietnam hotel industry. Journal of Cleaner Production, 13(2), 109-116.

United Nations World Tourism Organisation-UNWTO, 2018. UNWTO World Tourism Barometer, Volume 16, January 2018. Available from: 
http://cf.cdn.unwto.org/sites/all/files/pdf/unwto_barom18_01_january_excerpt_hr.pdf

[Accessed 18 June 2018].

Van Vuuren, C., and Slabbert, E., 2011. Travel motivations and behaviour of tourists to a South African resort. Tourism \& Management Studies, 1, 295-304.

Watkins, L., and Gnoth, J., 2011. The value orientation approach to understanding culture. Annals of Tourism Research, 38(4), 1274-1299.

Weaver, D., 2011. Can sustainable tourism survive climate change? Journal of Sustainable Tourism, 19(1), 5-15.

Weeden, C., 2011. Responsible tourist motivation: how valuable is the Schwartz value survey? Journal of Ecotourism, 10(3), 214-234.

Woodside, A.G., Hsu, S.Y., and Marshall, R., 2011. General theory of cultures' consequences on international tourism behavior. Journal of Business Research, 64(8), 785-799.

Yang, Y., and Wong, K., 2012. The Influence of Cultural Distance on China Inbound Tourism Flows: A Panel Data Gravity Model Approach. Asian Geographer, 29(1), 21-37.

Yoo, J., and Chon, K., 2008. Factors Affecting Convention Participation Decision-Making: Developing a Measurement Scale. Journal of Travel Research, 47(1), 113-122.

You, X., O’Leary, J., Morrison, A., and Hong, G., 2000. A Cross-Cultural Comparison of Travel Push and Pull Factors: United Kingdom versus Japan. International Journal of Hospitality and Tourism Administration, 1(2), 1-26.

Zhang, Y., Zhang, H-L., Zhang, J., and Cheng, S., 2014. Predicting residents' proenvironmental behaviors at tourist sites: The role of awareness of disaster's consequences, values, and place attachment. Journal of Environmental Psychology, 40, 131-146. 


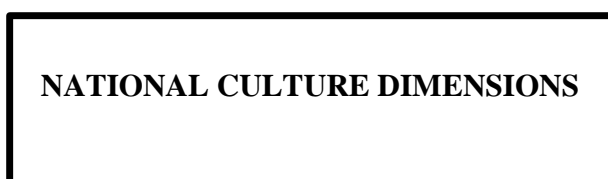

ENVIRONMENTALLY RESPONSIBLE BEHAVIORAL INTENTIONS

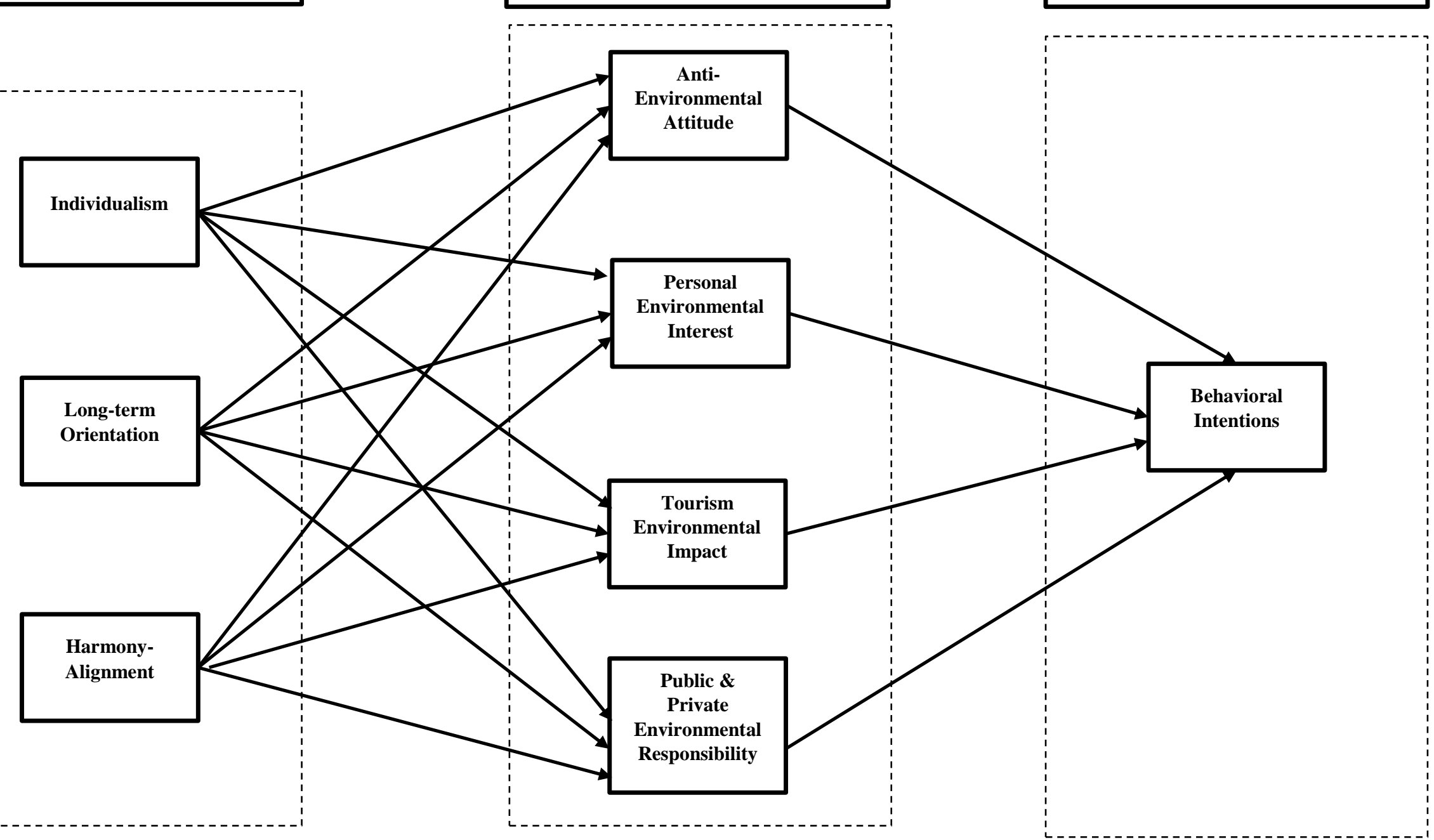

Figure 1. Conceptual model 


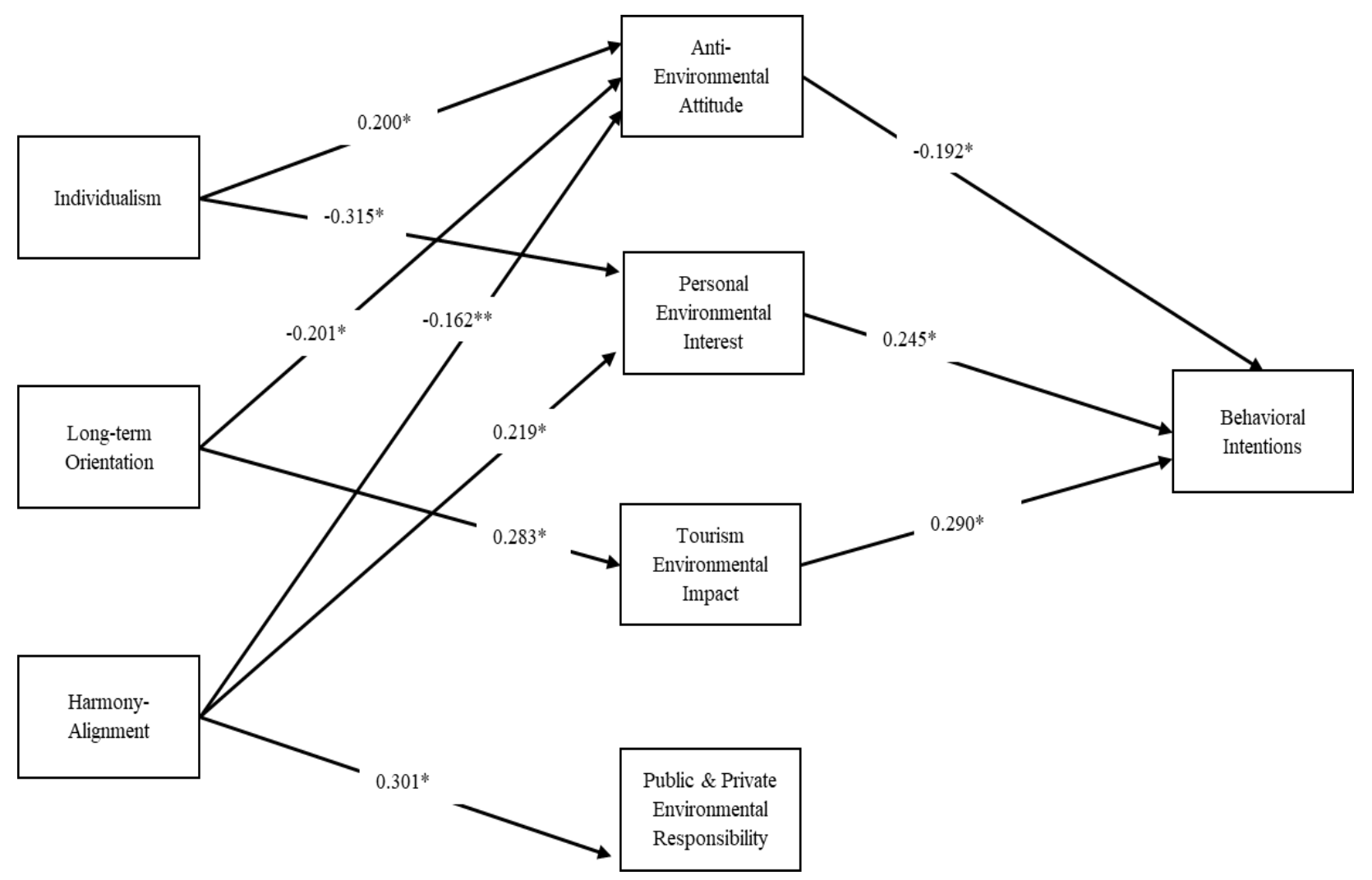

Note: ${ }^{*}=p<0.001 ;{ }^{* *}=p<0.01$.

Figure 2. Outcome of structural modeling 
Table 1. Sample profile $(n=454)$

\begin{tabular}{|c|c|c|c|}
\hline \multicolumn{2}{|l|}{ Gender } & \multicolumn{2}{|l|}{ Personal salary } \\
\hline $\begin{array}{l}\text { Male } \\
\text { Female }\end{array}$ & $\begin{array}{l}47.8 \% \\
52.2 \%\end{array}$ & $\begin{array}{c}\text { Below nation's average } \\
\text { Above nation's average } \\
\text { Refused / Prefer not to say }\end{array}$ & $\begin{array}{l}47.1 \% \\
17.8 \% \\
35.1 \% \\
\end{array}$ \\
\hline \multicolumn{2}{|l|}{ Level of education } & \multicolumn{2}{|l|}{ Occupation } \\
\hline $\begin{array}{c}\text { Secondary school } \\
\text { Technical education } \\
\text { University and above } \\
\text { No formal education / Other }\end{array}$ & $\begin{array}{c}35.5 \% \\
15.2 \% \\
43.4 \% \\
5.9 \%\end{array}$ & $\begin{array}{c}\text { Retired } \\
\text { Student } \\
\text { Unemployed } \\
\text { Full-Time employed } \\
\text { Part-Time employed } \\
\text { Other }\end{array}$ & $\begin{array}{c}16.1 \% \\
21.8 \% \\
5.5 \% \\
45.2 \% \\
7.3 \% \\
4.1 \%\end{array}$ \\
\hline \multicolumn{2}{|l|}{ Age } & \multicolumn{2}{|c|}{$\begin{array}{l}\text { Travelled abroad with holidaying purposes (in the } \\
\text { last } 3 \text { years) }\end{array}$} \\
\hline \multirow{3}{*}{$\begin{array}{c}16-24 \\
25-34 \\
35-44 \\
45-54 \\
55-64 \\
\text { over } 65\end{array}$} & \multirow{3}{*}{$\begin{array}{l}22.0 \% \\
18.9 \% \\
16.3 \% \\
18.7 \% \\
12.3 \% \\
11.8 \%\end{array}$} & $\begin{array}{l}\text { Yes } \\
\text { No }\end{array}$ & $\begin{array}{l}76.4 \% \\
23.6 \%\end{array}$ \\
\hline & & \multicolumn{2}{|c|}{ Frequency of travelling (per year) } \\
\hline & & $\begin{array}{c}\text { Average } \\
\text { Standard Deviation }\end{array}$ & $\begin{array}{l}1.79 \\
2.54\end{array}$ \\
\hline
\end{tabular}


Table 2. Environment-related cultural dimensions/value orientations for Poland. Source:

Adopted from Hofstede Centre (2017); Schwartz (2006)

\begin{tabular}{|c|c|c|c|}
\hline Cultural dimension & $\begin{array}{c}\text { Score for } \\
\text { Poland }\end{array}$ & Meaning & $\begin{array}{c}\text { Interpretation: Pro- } \\
\text { environmental attitudes are... }\end{array}$ \\
\hline Individualism/Collectivism & 60 out of 100 & Individualistic society & Low \\
\hline $\begin{array}{c}\text { Long-term/Short-term } \\
\text { orientation }\end{array}$ & 38 out of 100 & $\begin{array}{c}\text { Short-term oriented } \\
\text { society }\end{array}$ & Low \\
\hline Harmony/Mastery & Circa 0.83 & On the Harmony side & High \\
\hline
\end{tabular}


Table 3. Exploratory factor analysis (EFA) for pro-environmental attitudes of Polish tourists

\begin{tabular}{|c|c|c|c|c|c|c|}
\hline & \multicolumn{4}{|c|}{ Items factorial loadings } & \multirow[b]{2}{*}{$\begin{array}{c}\text { Arithmetic } \\
\text { mean }\end{array}$} & \multirow[b]{2}{*}{$\begin{array}{l}\text { Standard } \\
\text { Deviation }\end{array}$} \\
\hline Items & $\begin{array}{c}\text { Factor } \\
1\end{array}$ & $\begin{array}{c}\text { Factor } \\
2\end{array}$ & $\begin{array}{c}\text { Factor } \\
3\end{array}$ & $\begin{array}{c}\text { Factor } \\
4\end{array}$ & & \\
\hline Factor 1. Anti-Environmental Attitudes (AEA) & & & & & 3.11 & 0.85 \\
\hline Climate change is a natural phenomenon; people play no role in its intensifying & .723 & & & & 3.14 & 1.26 \\
\hline The environment has enough capacity to restore itself & .694 & & & & 3.10 & 1.17 \\
\hline Climate change is not my personal responsibility & .667 & & & & 2.90 & 1.23 \\
\hline People worry about climate change too much & .643 & & & & 3.31 & 1.17 \\
\hline Factor 2. Personal Environmental Interest (PEI) & & & & & 2.30 & 0.81 \\
\hline I try to reduce my impact on the environment in my day-to-day behaviour & & .788 & & & 2.47 & 1.03 \\
\hline I understand the notion of climate change & & .664 & & & 2.15 & 1.01 \\
\hline Factor 3. Tourism Environmental Impact (TEI) & & & & & 3.25 & 0.67 \\
\hline International tourism imposes significant impacts on climate change & & & .642 & & 3.19 & 0.97 \\
\hline Within tourism, air travel is the main contributor to climate change & & & .734 & & 3.37 & 0.96 \\
\hline Within tourism, hotels make the main contribution to climate change & & & .765 & & 3.52 & 0.88 \\
\hline
\end{tabular}




\begin{tabular}{|c|c|c|c|c|}
\hline I am aware of the climate implications of my holidays & .601 & & 2.94 & 1.11 \\
\hline $\begin{array}{l}\text { Commercial enterprises are the primary contributors to the problem of climate change } \\
\text { and hence they should be held responsible for fighting its negative implications }\end{array}$ & & .833 & 2.35 & 1.11 \\
\hline
\end{tabular}


Table 4. Descriptive statistics for the national culture dimensions and behavioral intentions as related to pro-environmental attitudes of tourists

\begin{tabular}{|c|c|c|c|}
\hline \multicolumn{2}{|c|}{ CULTURAL DIMENSIONS } & Average & $\begin{array}{l}\text { Standard } \\
\text { Deviation }\end{array}$ \\
\hline \multicolumn{3}{|c|}{ INDIVIDUALISM/COLLECTIVISM } & (higher scores indicate stronger Individualism). \\
\hline IND1 & $\begin{array}{l}\text { Nature is our common home and it is my personal responsibility } \\
\text { to look well after it (reversed item) }\end{array}$ & 1.87 & 0.82 \\
\hline IND2 & $\begin{array}{l}\text { I am more concerned about the effect climate change imposes } \\
\text { on myself rather than on this planet in general }\end{array}$ & 2.31 & 1.04 \\
\hline IND3 & $\begin{array}{l}\text { Environmental problems worry me little as I am just unable to } \\
\text { control them }\end{array}$ & 3.26 & 1.09 \\
\hline IND4 & $\begin{array}{l}\text { I am more concerned about the negative short-term effect of } \\
\text { climate change on me personally, than about the negative long- } \\
\text { term effect it imposes on the society as a whole }\end{array}$ & 3.14 & 1.06 \\
\hline \multicolumn{4}{|c|}{ (higher scores indicate stronger Long-Term Orientation) } \\
\hline LTOR1 & $\begin{array}{l}\text { Climate change will have a lot of long-term negative effects } \\
\text { while my life is too short to worry about it (reversed item) }\end{array}$ & 3.02 & 1.17 \\
\hline LTOR2 & $\begin{array}{l}\text { Environmental impacts will be the responsibility of future } \\
\text { generations and I am worried about it }\end{array}$ & 2.31 & 1.04 \\
\hline \multicolumn{4}{|c|}{ (higher levels scores more Harmony-Aligned Culture) } \\
\hline HARM1 & $\begin{array}{l}\text { Humans are masters of their own destiny and they have the } \\
\text { right to do whatever they want with nature as long as this can } \\
\text { help them achieve their goals (reversed item) }\end{array}$ & 3.83 & 1.13 \\
\hline HARM2 & $\begin{array}{l}\text { The environment is precious as this is where we live and we } \\
\text { should do as much as we can to minimize our negative impacts } \\
\text { on it }\end{array}$ & 1.90 & 0.82 \\
\hline HARM3 & $\begin{array}{l}\text { We have reached the stage in our development when the } \\
\text { environment should be governed and controlled by the humans } \\
\text { (reversed item) }\end{array}$ & 2.50 & 1.03 \\
\hline
\end{tabular}




\begin{tabular}{|c|l|c|c|}
\hline HARM4 & $\begin{array}{l}\text { Although the human civilization has become sophisticated } \\
\text { enough so that it is now able to control nature, the } \\
\text { environment will always fight back }\end{array}$ & 2.39 & 0.94 \\
\hline \multicolumn{1}{|c|}{ TOURIST BEHAVIOURAL INTENTIONS (TBI) } \\
$\quad$\begin{tabular}{|l|c|} 
(higher scores indicate stronger willingness to modify tourist behavior) \\
BI1
\end{tabular} & $\begin{array}{l}\text { In principle, I would consider changing my travel behavior to } \\
\text { make it more climate-friendly }\end{array}$ & 2.87 \\
\hline BI2 & $\begin{array}{l}\text { I do not want to change my travel behavior to make it more } \\
\text { climate-friendly simply because my personal efforts to fight the } \\
\text { problem of climate change are too small to make a noticeable } \\
\text { difference (reversed item) }\end{array}$ & 2.96 \\
\hline
\end{tabular}


Table 5. Results of the final measurement model. 


\begin{tabular}{|c|c|c|c|c|}
\hline Construct & Indicator & $\begin{array}{c}\text { Standardised } \\
\text { Loading }\end{array}$ & $\begin{array}{l}\text { Composite } \\
\text { Reliability } \\
\text { Index (CRI) }\end{array}$ & $\begin{array}{c}\text { Average } \\
\text { Variance } \\
\text { Extracted (AVE) }\end{array}$ \\
\hline $\begin{array}{c}\text { Individualism } \\
\text { IND }\end{array}$ & $\begin{array}{l}\text { IND1 } \\
\text { IND2 } \\
\text { IND3 }\end{array}$ & $\begin{array}{l}0.738^{*} \\
0.624 * \\
0.784^{*}\end{array}$ & 0.760 & 0.516 \\
\hline $\begin{array}{c}\text { Long-term Orientation } \\
\text { LTOR }\end{array}$ & $\begin{array}{l}\text { LTOR1 } \\
\text { LTOR2 }\end{array}$ & $\begin{array}{l}0.793^{*} \\
0.804^{*}\end{array}$ & 0.779 & 0.638 \\
\hline $\begin{array}{c}\text { Harmony-Aligned } \\
\text { HARM }\end{array}$ & $\begin{array}{l}\text { HARM1 } \\
\text { HARM2 }\end{array}$ & $\begin{array}{l}0.872^{*} \\
0.870^{*}\end{array}$ & 0.863 & 0.758 \\
\hline $\begin{array}{c}\text { Anti-Environmental } \\
\text { Attitudes } \\
\text { AEA }\end{array}$ & $\begin{array}{l}A E A 1 \\
A E A 2 \\
A E A 3 \\
A E A 4\end{array}$ & $\begin{array}{c}0.667^{*} \\
0.753^{*} \\
0.713^{*} \\
0.699^{*}\end{array}$ & 0.801 & 0.501 \\
\hline $\begin{array}{c}\text { Personal } \\
\text { Environmental Interest } \\
\text { PEI }\end{array}$ & $\begin{array}{l}\text { PEI1 } \\
\text { PEI2 }\end{array}$ & $\begin{array}{l}0.829 * \\
0.770^{*}\end{array}$ & 0.780 & 0.640 \\
\hline $\begin{array}{c}\text { Tourism } \\
\text { Environmental Impact } \\
\text { TEI }\end{array}$ & $\begin{array}{l}\text { TEI1 } \\
\text { TEI2 } \\
\text { TEI3 } \\
\text { TEI4 }\end{array}$ & $\begin{array}{l}0.721^{*} \\
0.708^{*} \\
0.715^{*} \\
0.675^{*}\end{array}$ & 0.798 & 0.497 \\
\hline $\begin{array}{c}\text { Public and Private } \\
\text { Environmental } \\
\text { Responsibility } \\
\text { PPER }\end{array}$ & $\begin{array}{l}\text { PPER1 } \\
\text { PPER2 }\end{array}$ & $\begin{array}{l}0.867^{*} \\
0.814^{*}\end{array}$ & 0.828 & 0.707 \\
\hline $\begin{array}{c}\text { Tourist Behavioral } \\
\text { Intentions } \\
\text { TBI }\end{array}$ & $\begin{array}{l}\text { TBI1 } \\
T B \mid 2\end{array}$ & $\begin{array}{l}0.856^{*} \\
0.776^{*}\end{array}$ & 0.800 & 0.668 \\
\hline
\end{tabular}

Note: ${ }^{*}=p<0.001$. 
Table 6. Discriminant validity of the final measurement model.

\begin{tabular}{|c|c|c|c|c|c|c|c|c|}
\hline Construct & $\mathbf{1}$ & $\mathbf{2}$ & $\mathbf{3}$ & $\mathbf{4}$ & $\mathbf{5}$ & $\mathbf{6}$ & $\mathbf{7}$ & $\mathbf{8}$ \\
\hline 1. IND & 0.719 & & & & & & & \\
\hline 2. LTOR & -0.585 & 0.799 & & & & & & \\
\hline 3. HARM & -0.638 & 0.525 & 0.871 & & & & & \\
\hline 4. AEA & 0.420 & -0.403 & -0.395 & 0.708 & & & & \\
\hline 5. PEI & -0.488 & 0.356 & 0.449 & -0.275 & 0.800 & & & \\
\hline 6. TEI & -0.234 & 0.307 & 0.187 & -0.248 & 0.141 & 0.705 & & \\
\hline 7. PPER & -0.229 & 0.233 & 0.337 & -0.374 & 0.290 & 0.274 & 0.841 & \\
\hline 8. TBI & -0.491 & 0.532 & 0.428 & -0.340 & 0.341 & 0.366 & 0.221 & 0.817 \\
\hline
\end{tabular}

Note 1: Values in the diagonal indicate the squared root of the AVE values; values above the diagonal represent the latent variables' correlations.

Note 2: See Table 1. 
Table 7. Results of structural modeling

\begin{tabular}{|c|c|c|}
\hline Structural paths & $\beta$ & t-value \\
\hline \multicolumn{3}{|l|}{ Cultural dimensions $\rightarrow$ Pro-environmental attitudes } \\
\hline Individualism $\rightarrow$ Anti-environmental attitude & 0.200 & $3.486^{*}$ \\
\hline Individualism $\rightarrow$ Personal environmental interest & -0.315 & $4.875^{*}$ \\
\hline Individualism $\rightarrow$ Tourism environmental impact & -0.084 & 1.200 \\
\hline Individualism $\rightarrow$ Public \& private environmental responsibility & 0.010 & 0.170 \\
\hline Long-term orientation $\rightarrow$ Anti-environmental attitude & -0.201 & $3.687^{*}$ \\
\hline Long-term orientation $\rightarrow$ Personal environmental interest & 0.057 & 0.976 \\
\hline Long-term orientation $\rightarrow$ Tourism environmental impact & 0.283 & $4.872^{*}$ \\
\hline Long-term orientation $\rightarrow$ Public \& private environmental responsibility & 0.081 & 1.239 \\
\hline Harmony-Aligned $\rightarrow$ Anti-environmental attitude & -0.162 & $2.911 * *$ \\
\hline Harmony-Aligned $\rightarrow$ Personal environmental interest & 0.219 & $3.532 *$ \\
\hline Harmony-Aligned $\rightarrow$ Tourism environmental impact & -0.003 & 0.055 \\
\hline Harmony-Aligned $\rightarrow$ Public \& private environmental responsibility & 0.301 & $4.586^{*}$ \\
\hline \multicolumn{3}{|l|}{ Pro-environmental attitudes $\rightarrow$ Behavioral intentions } \\
\hline Anti-environmental attitude $\rightarrow$ Behavioral intentions & -0.192 & $3.928^{*}$ \\
\hline Personal environmental interest $\rightarrow$ Behavioral intentions & 0.245 & $5.163^{*}$ \\
\hline Tourism environmental impact $\rightarrow$ Behavioral intentions & 0.290 & $5.903^{*}$ \\
\hline Public \& private environmental responsibility $\rightarrow$ Behavioral intentions & -0.003 & 0.068 \\
\hline \multicolumn{3}{|c|}{$R^{2}(A E A)=22.9 \% ; R^{2}(P E I)=27.2 \% ; R^{2}(T E I)=11.4 \% ; R^{2}(P P E R)=11.8 \% ; R^{2}(B I)=25.8 \%$} \\
\hline \multicolumn{3}{|c|}{$Q^{2}(A E A)=0.107 ; Q^{2}(P E I)=0.160 ; Q^{2}(T E I)=0.049 ; Q^{2}(P P E R)=0.073 ; Q^{2}(B I)=0.154$} \\
\hline
\end{tabular}

Note 1: See Table 1.

Note $2:^{*}=p<0.001 ;{ }^{* *}=p<0.01$. 